\title{
Art, territori i nou paradigma comunicatiu: un compendi d'artistes borrianencs ${ }^{1}$
}

\author{
Aina Monferrer PAlmer (aina.monferrer@uji.es) \\ Universitat Jaume I
}

\section{Introducció}

Borriana és un poble d'artistes. I com més en busquem, més en trobem. De moment, amb uns noranta artistes de tota mena, aquest treball de recerca s'atura perquè l'ànim d'exhaustivitat també té un límit. En començar a pensar la qüestió ens hem hagut de plantejar sobretot dues preguntes: què és l'art? què es considera ser de Borriana? Existeixen moltes definicions del concepte subjectiu i polisèmic d'art; unes de més reduccionistes, altres de més ambigües, i cadascuna posa l'èmfasi en un dels elements: el procés, l'autoria, el receptor, la funció, etc. Una definició útil per al nostre estudi és la consideració d'obra d'art com qualsevol manifestació original d'un ésser humà o d'una collectivitat que té raons estètiques i que pretén una comunicació subjectiva i reflexiva de la realitat amb l'ús d'unes tècniques determinades i premeditades.

Pel que fa a la segona qüestió, què és ser borrianenc, tot i que és una qüestió molt més clara que la de l'art, també planteja alguns dubtes. Hem considerat borrianenc o borrianenca qualsevol persona nascuda a Borriana o que hi ha viscut un temps considerable, potser perquè hi estiueja, o potser perquè hi ha residit algunes temporades. El darrer dels termes que hauríem de definir és el d'artista. Hem considerat artista qualsevol creador o creadora amb un mínim de resò social, siga per publicacions, exposicions, premis o altres tipus de reconeixements del seu treball artístic. D'altra banda, és innegable que l'atzar i la mateixa subjectivitat de qui ací escriu hauran condicionat, si més no mínimament, l'elenc de creadors d'art biogràficament lligats a Borriana, els quals han estat seleccionats amb la màxima bona fe i rigor per a aquest treball.

Ens plantegem quina relació tenen els artistes i Borriana: hi ha qui, com el pintor Traver Calzada, viu arrecerat al seu xalet on treballa l'art amb amor al seu poble, amb un sentiment paradoxal de pertinença i alhora d'invisibilitat veïnal. Hi ha qui, com el violinista Gerard Mesado, se'n va anar fora fa un bon grapat d'anys i només torna de visita. Altres, com el cartellista Juan Ingelmo, en són fills adoptius, i encara uns altres, com Francesc Tàrrega, Lucrecia Bori o Amat Bellés, han viscut gens o a penes a Borriana, però els seus lligams amb aquest poble de malnom porcí són innegables i per això tenim dret a sentir-nos-els un poc nostres, almenys.

També ens intriga la qüestió de com aquest poble (el clima, la idiosincràsia dels seus habitants, la situació geogràfica, la història i la cultura) han pogut condicionar els artistes

\footnotetext{
${ }^{1}$ Aquest treball s'inscriu en el marc del projecte d'investigació de la Universitat Jaume I «El discurs divulgatiu en català i en espanyol: gèneres, estils i estratègies argumentatives en la gestió social dels coneixements» (PB2011-53).
} 
i l'art que s'hi fa o s'hi ha fet, especialment els dos darrers segles. I sobretot ens interessen els llocs fronterers de l'art, on s'entremesclen les diferents tècniques i disciplines (pintura i cartellisme, poesia i música) i també on l'art s'imbrica amb altres esferes socials com el negoci i l'artesania (bijuteria, ceràmica, modisteria i gastronomia, entre d'altres); llàstima que les restriccions d'espai frenen les nostres expectatives.

Sense subterfugis: mirarem d'analitzar els artistes del passat per a comprendre sobretot l'art del present en relació amb Borriana i amb una visió d'ambicions prospectives, basada en el potencial humà i la conjuntura social que ara tenim i que podem albirar.

\section{Els llocs de l'art a Borriana}

L'art és un fet eminentment social i centrípet. Normalment, perquè hi haja bons artistes, s'ha de crear escola; però l'escola no es pot crear si no és entre un colllectiu de gent. Per a això, han calgut persones i llocs centrals de la cultura que han format nous artistes i han creat ambients culturals propicis. A Borriana, aquests llocs han existit en diverses èpoques i per a diversos arts. Un cas especialment destacat en aquest sentit és el de les escoles de música i les bandes borrianenques, que a l'alba del segle xx n'eren dues en plena renaixença econòmica, gràcies al comerç de la taronja. Unes dècades més tard, l'any 1954 es va crear l'Agrupació Borrianenca de Cultura (ABC). Una altra vegada trobem que un període de prosperitat econòmica implica un augment del dinamisme cultural local. Aquesta vegada a través d'aquesta nova associació de caràcter valencianista i lligada a Lo Rat Penat, però amb una clara vocació més culturalista que política, i gràcies a la qual es poden llegir aquestes paraules.

Altrament, hi ha hagut molts collectius que han estat centres locals dinamitzadors de la cultura, però sense que aquesta fóra a priori la seua raó de ser. Pensem, si no, en la casa del músic Pasqual Rubert, en les classes de pintura de l'Acadèmia Municipal d'Art (AMA), gràcies a l'obstinació d'un jove Traver Calzada i que són el germen de creació de l'actual Casa de la Cultura; però també en les falles com a centres de la cultura fallera, en els centres juvenils Porta Oberta o l'Agrupament Escolta o bé altres iniciatives, més o menys efímeres, les quals han sorgit entre la joventut local (la Milotxa, l'Escletxa, etc.), però que s'han volatilitzat ben ràpidament. I encara més: hi ha hagut alguns locals que s'han convertit en sales d'exposicions i de concerts com és el cas del desaparegut pub Jamaica (escenari d'un llibre de relats de ficció de Josep M. Chordà), i ara del pub Naraniga, que s'ha consolidat com un espai de dinamització cultural i lloc de reunió de joves - i no tan joves - artistes locals i provincials.

A més, cal tenir en compte que, arribats a l'era d'Internet, la dinamització cultural es deslocalitza; ara es pot formar part de collectius artístics globalitzats que permeten els artistes estar connectats amb artistes afins d'arreu del món més enllà de les fronteres geogràfiques. No obstant això, els centres culturals locals no perden ni vigència ni importància, sinó que queden complementats. En els següents apartats farem el que podrem per a omplir les cel·les, com més millor, d'aquest rusc immens i multidimensional que és l'art borrianenc.

\section{Arts plàstiques}

La pintura és la disciplina antonomàstica de les arts plàstiques. L'ofici de les belles arts ha estat afició confessada de nombrosos borrianencs, alguns dels quals molt lligats al 
món de les falles i d'altres no tant, o no gens. Llevat d'uns pocs moments crítics, des de la creació de l'ABC, l'any 1954, fins avui, han existit concorreguts tallers per a aprendrehi les diferents tècniques pictòriques i escultòriques. El primer centre d'aquest tipus que coneixem va ser l'Escola de Dibuix i Pintura de l'ABC que va començar a funcionar l'any 1954. Deu anys després es va suprimir per raons econòmiques (Roselló, 2009: 15). A més, de 1966 a 1991 va funcionar un estudi dependent del Col·legi dels Carmelites (l'actual col·legi Illes Columbretes) que regentava un religiós: Juan de Dios Morenilla.

Però hi ha una iniciativa de l'any 1973 especialment important perquè va ser la llavor del que avui coneixem com Centre Municipal d'Estudis (CME) Rafel Martí de Viciana, altrament conegut com la Casa de la Cultura del nostre poble. Parlem de l'AMA, creació i sacrifici del nostre més il-lustre pintor, Vicent Traver Calzada. L'AMA va ser fruit de l'empenta i la il·lusió d'un jove pintor borrianenc, fill d'artista faller però amb un domini de les tècniques diverses de les belles arts i minuciositat inusitades als antípodes del món del paper cartró. L’Ajuntament va cedir un local precari al carrer de Jesús perquè Traver Calzada hi engegara, de manera altruista, l'AMA. Aquesta va durar quatre anys i entre els seus nombrosos alumnes es pot comptar el fotògraf Joaquim Bosch.

L'espurna de l'AMA, avivada pels temps de canvi i afanys d'obertura que bufaven en aqueixos anys, va motivar tot un collectiu de gent de la cultura en general. Músics com Pasqual Rubert, Gerard Mesado, juntament amb l'arqueòleg Norbert Mesado, i més gent van aplegar forces per a reivindicar una casa de cultura per al poble. Finalment, ho van aconseguir. Era l'any 1990. A poc a poc, la Casa de la Cultura ha crescut, s'ha estès sempre des de l'antic convent de la Mercè, que va ser presó feixista els anys de la guerra. Després de tant d'esforç, quan les aigües ja baixaven clares, Traver Calzada va llegar les classes de dibuix del CME a Tomàs Sendra i a Amelia Gual, que hi han ensenyat dibuix, pintura $\mathrm{i}$ escultura a moltes generacions de borrianencs. Altres centres d'arts plàstiques a la Borriana del període democràtic han estat l'estudi Gama, al carrer Sant Vicent, centre privat, i el taller de pintura organitzat per la Caixa Rural a l'edifici de la Carrera.

L'afecció a la pintura i a la fotografia a Borriana és substancial. Les classes de què acabem de parlar han fet que molts borrianencs practiquen la pintura en el temps de lleure o fins i tot de manera quasi professional. Tanmateix, hem hagut de triar. Hem deixat de banda els pintors de falla, que tenen el seu lloc en el capítol 2 d'aquest llibre. Pel que fa als escultors, en destaquem dos noms: Sergio Cabedo i Santiago Soro. Tots dos són escultors i alhora artistes fallers, i Cabedo treballa sovint per al pintor i escultor d'Alzira, resident a Sant Joan de Moró, l'arxiconegut Juan Ripollés, en la construcció de les grans figures metàl-liques que caracteritzen alguns dels seus treballs.

A partir d'una primera impressió sobre l'estil i les tècniques pictòriques utilitzades, hem dividit els principals pintors en tres grups: els tradicionalistes, els híbrids i els abstractes. Quant als tradicionalistes, Juan González Alacreu (1937) va començar com a dibuixant de còmics i illlustrador de llibres infantils. La seua pintura, de temàtica costumista valenciana, recorda, pel traç i per la paleta, Joaquim Sorolla. Juan Dualde (1940) també fa pintura costumista amb detalls de la mar i de la taronja, i sovint apareixen en les seues teles enquadraments fàcilment identificables per qualsevol borrianenc. Això també passa sovint en la pintura de Vicent Guerola. Retolista d'ofici, però amb bategants inquietuds artístiques, aquest pintor ofereix una gamma de colors més reduïda que els anteriors, i 
mostra preferència pels paisatges urbans borrianencs en sèpia o en blanc i negre, on sovint busca el realisme amb rigor gairebé fotogràfic. Guerola és interessant també pels intents que ha fet en algunes ocasions per connectar la seua obra plàstica amb els versos del poeta Vicent Andrés Estellés.

En segon lloc parlem ara dels híbrids: aquells pintors que, per temàtica, per tècniques i per estil, no se cenyeixen a un reflex tradicional de la realitat. Vicent Traver Calzada (1945) és un pintor excepcional, especialment perquè ha arribat a l'excel·lència en el domini de tècniques pictòriques molt diverses, a més de conservar la manera artesanal de confeccionar les pintures que utilitza. Així, el seu treball artístic és també el de l'infatigable artesà i la seua meticulositat en l'elaboració és màxima. Les seues capacitats per a la pintura figurativa són encomiables i alguns dels seus treballs, de detall hiperrealista, recorden el pintor de Tomelloso Antonio López.

Calzada defuig tota mena de megalomania. No va a ARCO ni a les grans fires de l'art. Ell diu que no vol ser artista, que l'única cosa que vol ser és bon pintor. La seua manera d'art persegueix el rigor i que tots els elements i processos d'un quadre es justifiquen per un perquè meditat. La seua aparença física és inconfusible per la barba i els cabells blancs i abundosos, però no per cap projecció pública. Ningú no és profeta en terra pròpia, però potser les lloances i reconeixements locals vindran post mortem, quan ja siga massa tard per a traure profit local d'aquestes mans i cervell generosos, però poc tinguts en consideració.

Pepe Forner (1955) és un altre pintor local. La temàtica de les seues obres no s'escapa del que és previsible pel que fa als temes. Una o diverses figures humanes solen ser les protagonistes dels seus quadres. El seu traç és poderós i la paleta de color és variada, intensa i amb certa predilecció pels grocs. Tot i les diferents tècniques i estils que utilitza, uns més a prop del llapis, uns altres més de la brotxa, sempre reconeixem la figura humana en els seus quadres, no com en el cas de Vicent Carda, que veurem ara. Carda (1962) és un pintor no figuratiu. Alguns dels seus treballs, basats en la seriació, amb traços gruixuts i colors i formes que recorden figures vegetals o aquàtiques i alhora textures de paret antiga, evoquen sovint Antoni Tàpies. Vet ací una definició més tècnica:

Cabe señalar dos constantes tan obvias como sugerentes [referents a l'obra de Vicent Carda]: los elementos figurativos aparecen reducidos a su mínima dimensión gráfica, y en la relación figura-fondo, el espacio pictórico se percibe como un lugar vacío (aire) en el que flotan los signos plásticos. ${ }^{2}$

A més de pintor, Vicent Carda també treballa, des de 2006, com a gestor d'art a través de la seua empresa Espais d'Art. Víctor Meliá Dealba (1983) és l'últim nom d'aquesta llista escadussera de pintors borrianencs. De fet, Dealba no és exactament un pintor, sinó un artista visual que crea les seues obres en suport bidimensional d'imatge fixa. És, en definitiva, un artista conceptual. Dealba és un pensador de l'art que reflexiona sobre les fronteres artístiques amb els seus treballs. Així, podríem dir que les seues obres són metareflexions sobre l'art a través de l'art. I sobre la realitat. Un dels seus leitmotiv és la reflexió sobre l'invisible del real. La imatge fotogràfica té, però, un pes important en les creacions de Dealba.

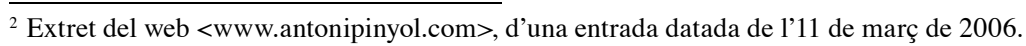


Hem dividit la nostra selecció de fotògrafs de manera cronològica en tres parts. La primera és la dels antics: José Luis Garcia Ferrada (1935) i Joaquim Bosch (que naix a Almussafes, el 1930, però que amb vint anys se'n ve a viure a Borriana) són dos fotògrafs guardonats en moltes ocasions en concursos de fotografia del territori espanyol. De la fornada dels anys cinquanta i seixanta, destacarem tres fotògrafs: Joan Antoni Vicent, Ramon Usó i Jordi Font de Mora. Vicent, que és de la Vall d'Uixó però estiueja a Borriana, té predilecció pel blanc i negre. És un caçador de paisatges de ciutat i té ben assumida la funció narrativa de la fotografia. Darrerament, ha col-laborat amb l'escriptor Joan Garí per a il·lustrar la nova versió d'El País Valenciano fusterià, de 1962, titulat Viatge pel meu país (2012).

Jordi Font de Mora va nàixer a Barcelona, l'any 1966, on sa mare tenia un estudi de fotografia. Font de Mora es va instal-lar a Borriana quan tenia 23 anys i va crear, juntament amb el dissenyador Jean-Paul Aznar, Plató: una de les agències de publicitat de més història del nostre poble. Aquest fotògraf publicitari va ser guardonat l'any 1985 amb el premi al millor fotògraf català de l'any. Perfeccionisme i constància són els adjectius que millor descriuen aquest minuciós fotògraf d'estudi. Perfeccionisme i textures són adjectius per al següent fotògraf borrianenc. Ramon Usó és un fotògraf del color. Les seues instantànies són molt lluminoses i transmeten sempre força. Té preferència pel personatge de la dona. El seu extens i potent treball no deixa espai al dubte sobre la seua qualitat com a fotògraf.

Els de la primera fornada eren fotògrafs analògics, els de la segona són conversos i els que ara citaré, forjats en el digital, són partícips d'una certa tornada nostàlgica al carret i a l'ampliadora. És el cas de José Carlos de la Torre (àlies Artinwreck) fotògraf artístic borrianenc que actualment treballa la fotografia analògica en blanc i negre. A més, De la Torre forma tàndem artístic amb la dibuixant Paula Fernández (àlies Dudelsea, que és d'Oviedo, però a hores d'ara viu a Borriana). Junts són Wreck at Sea i ofereixen un treball de fotografia amb afegitons pintats que donen als enquadraments fotogràfics d'allò més quotidians una visió fantàstica i d'aspecte naïf. Per a tancar el grup dels fotògrafs, parlarem d'una jove, Wayre Arnal (les Alqueries), que emmarca el seu treball fotogràfic en una concepció estètica en sintonia amb les darreres tendències estètiques europees. De la Torre i Arnal són, si més no, dues promeses de futur de la instantània borrianenca. Es veu clarament també com aquest darrer grup dels fotògrafs més novells sap posicionar-se en els llocs de l'art i ha captat com funciona l'organització rizomàtica de la informació en Internet: xarxes socials com Pinterest, Instagram o la plataforma de microblogs per a artistes, Tumblr. Nous temps, nous canals.

Pel que fa al cartellisme cal destacar el pintor Amat Bellés (nascut el 1949 a la Pobla Tornesa, però amb un estret i llarg lligam amb Borriana). Els seus cartells, de tonalitats suaus, que sovint mostren muntatges de dones dibuixades sobre paisatges pintats, han publicitat la Universitat Jaume I durant els seus més de vint anys de vida. Un altre cartellista vinculat amb Borriana és Juan Ingelmo (1976), els cartells del qual, d'un marcat geometrisme en els contorns, han estat triats per anunciar les festes patronals de pobles i ciutats arreu de l'Estat.

No voldria deixar de citar Vicent Aleixandre per la seua prolixitat local i per l'estil inconfusible dels seus cartells, i amb ell, un grup d'artistes underground nascuts als setanta que han assolit cert prestigi entre els seus companys d'ofici. Ens referim als grafiters Joe i Paquito, als tatuadors Jorge Musoles i Felipe i, en darrer lloc, als decoradors de vehicles Raúl Godos i José María Giner, que formen la marca Imaginart Factory. 


\section{Cinema}

Hi ha tres borrianencs que es mouen en l'elit cinematogràfica espanyola: el productor Gustavo Ferrada Lavall (1963), el director, productor i guionista Vicent Monsonís, àlies Monso (1968), i el dissenyador d'efectes especials Juan Serrano (1976). Justament el més jove és qui ha arribat més amunt, ja que té un Òscar pel seu treball en la pelllícula $E l$ laberinto del fauno. Des de la seua empresa amb seu a Barcelona anomenada Gadget Efectos Especiales, ofereix serveis per a tota mena de muntatges audiovisuals. Ha treballat en altres superproduccions com Hellboy i Ágora.

Vicent Monsonís és un dels realitzadors capdavanters del cinema al País Valencià. Ha rodat pel-lícules com Dripping, Mi último verano con Marián i Vida robada, les dues últimes compten amb escenaris borrianencs. Ha participat, com a productor, en la seua pel-lícula Dripping amb una altra borrianenca, Claudia Peris. Encara li queda molta carrera cinematogràfica per davant i segurament ampliarà el seu currículum com a artista de la imatge en moviment. El més gran dels tres cinèfils locals és Gustavo Ferrada (1963). Ha estat productor de la hilarant El milagro de P. Tinto, de Crimen ferpecto, d'El Camino de los Ingleses i de La Caja 507, entre d'altres pellícules. Ha treballat com a productor per a TVE, per al grup Sogecable i per a la Ciutat de la Llum. De fet, és considerat un dels productors més destacats del cinema espanyol actual (Ríos, 2009: 10).

Podríem considerar que un productor de cinema com Ferrada és un gestor d'art, i així enllaçaríem amb l'últim però imprescindible home d'art que citarem en aquest punt del capítol. Manuel J. Borja-Villel (1957) és un historiador de l'art, veí de Borriana, que ha dirigit els millors museus de l'Estat espanyol. Ha estat director artístic de la Fundació Antoni Tàpies de 1990 a 1998. Aquell mateix any va ser nomenat director del Museu d'Art Contemporani de Barcelona (MACBA). Des de l'any 2008 és director del Museu Reina Sofía de Madrid. De fet, Borja-Villel és el responsable de l'exposició sobre Salvador Dalí que té lloc d'abril a setembre de 2013 al Reina Sofía i que és la més visitada de la història de la capital.

\section{Música}

Borriana ha tingut molt bons músics. Potser la música ha estat el més prolífic i reeixit art a Borriana. Escorcollant una mica es pot trobar fàcilment informació sobre músics borrianencs de molta qualitat que no han parat de sorgir des del segle XIX fins als nostres dies, i Borriana ha comptat amb centres de música almenys des del segle XIX. A començaments del segle XX hi havia dues bandes municipals: la Filharmònica i la Lira Juvenil, que també s'anomenà la banda de la Creu Roja i que era coneguda com La Xicoteta (Buris-ana, 2005: 5).

També hi havia aleshores l'Acadèmia de Música de Corda, dirigida per Vicent Tàrrega, germà del virtuós de la guitarra Francesc Tàrrega. D’aquesta Acadèmia sorgiren bons músics de corda, entre els quals va destacar Abel Mus (1907-1983). Aquest violinista va esdevenir un dels millors d'Espanya, amb un èxit professional àmpliament acreditat, malgrat els perjudicis que li va causar la seua filiació antifranquista. Professor del Conservatori de París, violí solista de l'orquestra del Liceu de Barcelona i solista també de l'orquestra municipal de València, dirigida per Josep Iturbi, són algunes de les seues fites. 
Un altre músic borrianenc que va eixir de l'Acadèmia de Música de Corda va ser Ismael Cerezo, qui va arribar a ser violoncel solista de l'Orquestra Simfònica de Madrid. Un poc més vell que Mus i Cerezo era el violinista Joaquim Monsonís i Rivera, del qual se sap que va ser un violinista de reconegut prestigi a València (Buris-ana, 2005: 6) i que va morir, no massa vell, a Borriana, per una malaltia, fet que li va impedir arribar més lluny com a solista de l'instrument més fi dels de corda. Hi ha una curiosa història que lliga els dos grans violinistes i que ha estat contada per un altre violinista de Borriana, deixeble d'Abel Mus, com és Gerard Mesado (2005: 10-12).

Com molt amablement conta Gerard Mesado, a finals del segle xıx, en plena esplendor tarongera de la capital de la Plana Baixa, hi havia a Borriana un comerciant de taronja italià, gran melòman i filantrop, anomenat Antonio Cánesa Mendaya. Pels volts d'aqueixos anys hi havia certs músics que es guanyaven la vida tocant als cafès de l'època, especialment al Casino Borrianenc i al Café de Zapater. Cánesa va exercir de mecenes de dos d'ells: el guitarrista Francesc Tàrrega Eixea i el violinista Joaquim Monsonís Rivera. A Francesc Tàrrega li va regalar una Antonio Torres, la millor guitarra d'aquells temps. Per a Monsonís va ser un Rugieri de Cremona espectacular, que no va poder lluir en els grans escenaris que hauria volgut a causa d'una malaltia fulminant. Aleshores, en morir Monsonís, Abel Mus va voler comprar-li l'instrument a la seua dona. I així, entre borrianencs va anar la cosa i el violí va poder trepitjar els escenaris que es mereixia de la mà de Mus, que el va tindre amb ell, com un apèndix del seu braç, fins a la mort.

Conta Mesado com, de tant en tant, Abel Mus, el seu mestre de violí, li deixava el Rugieri, però per poc de temps, ja que la síndrome d'abstinència li venia en unes poques hores i havia d'anar a tornar-li'l sense haver-lo gaudit tot el que hauria volgut. Hauria estat bonic que aquest anhelat instrument haguera passat per tercera vegada a mans d'un borrianenc i violinista, però el cas és que, en morir-se Mus, se'n va perdre la pista. Gerard Mesado ha estat també solista de l'orquestra del Liceu de Barcelona i fa molts anys que viu i treballa de violinista a Alemanya, on va formar família i on s'ha quedat a viure. El cas de Gerard Mesado també és un cas de trencar barreres. Va començar a tocar als dinou anys i, malgrat el desencoratjament que va patir per part de professors de violí de València que el consideraven massa major per a dedicar-s'hi professionalment, la seua tenacitat va poder amb tot. De la mà de l'obstinat violinista Abel Mus va aconseguir la seua fita i es va convertir en un violinista de qualitat consolidada i incontestable (Mesado, 2005: 10).

Joaquim Monsonís, Abel Mus i Gerard Mesado han estat els tres millors violinistes borrianencs i el que va arribar més lluny va ser Mus. Sobta el fet que, pels volts del 1927, Abel Mus comptava amb un club de fans, la Penya Mus, talment com si es tractara d'un jugador de futbol o d'un cantant popular d'ara (Mesado, 2005: 12). Actualment, hi ha un violinista, nascut l'any 1987, que està fent el seu camí per les orquestres provincials amb qualitat tècnica i versatilitat destacables: Pedro Gilabert.

Al llarg del segle xx, Borriana ha albergat grans músics i músiques, dels quals ara intentem oferir-ne una panoràmica, encara que limitada per causa de l'espai. Vicent Soler fou un bon guitarrista i violoncel-lista, deixeble de Francesc Tàrrega. La seua filla, la pianista Lolita Soler (1938), ha estat durant molts anys professora de música i de piano a Borriana i a Castelló, però també ho va ser durant uns anys a Lisboa. El psiquiatre nordamericà Oliver Sacks afirma el que la història i la tradició han demostrat durant segles: les 
persones amb deficiències visuals desenvolupen un sentit especialment virtuós i sensible per a la música. És el cas del músic borrianenc Pasqual Rubert. Aquestes persones que no veuen utilitzen altres sentits, especialment els relacionats amb l'oïda, molt més que la resta, fet que els converteix en superdotats per a la música i capaços de gaudir-la i de comprendre-la d'una manera especialment profunda (Sacks, 2008: 160-164).

Entre els antics, i pel que fa a les veus, hi ha dues figures borrianenques que han triomfat en diferents àmbits de l'escena musical nacional i internacional. Ens referim a Lucrecia Bori (1887-1960) i a Juan Varea Segura (1908-1985). Lucrecia Natividad Borja González de Riancho no va nàixer a Borriana, sinó a València. La considerem borrianenca perquè son pare i els seus avis eren de Borriana i perquè, a més, hi va passar els seus anys d'infantesa i adolescència. Son pare era Vicent Borja Bonet, comandant d'infanteria (Mesado, 2005: 13). Lucrecia Bori és considerada per alguns una de les millors sopranos de la història i va obtenir el seu gran èxit als Estats Units. Va residir a Nova York durant molts anys i allí va morir. D’altra banda, el borrianenc Juan Varea és considerat una de les veus clàssiques del flamenc. Va començar la seua carrera artística a Barcelona i després de tota la vida dedicada a aquest cant va ser reconegut com un dels millors del flamenc amb el premi a la Mestria, atorgat per la Cátedra de Flamencología de Jerez de la Frontera.

De les veus antigues, falta esmentar la cantant lírica Rosa Adelfa Ballester. Si pensem ara en les veus noves, hem de citar les corals borrianenques. Actualment n'hi ha dues: la Coral Borrianenca, amb la seua secció infantil i juvenil, i el Cor Carnevale. La Coral Borrianenca va ser fundada l'any 1983 per alguns dels qui actualment formen part del Cor Carnevale, entre els quals, l'actual director del Cor Carnevale, Josep Ramon Calpe Saera, melòman confessat. Abans hi havia l'Orfeó Borrianenc, així que el cant, a Borriana, almenys els dos darrers segles, ha estat cultivat bastament. De la Coral Borrianenca ha sortit la millor veu femenina actual de la capital de la Plana Baixa: Minerva Moliner. Aquesta cantant borrianenca, nascuda als anys setanta, ha tingut diversos èxits nacionals com a solista d'òpera. Encara és jove, així que és massa prompte per avaluar la seua trajectòria, però segueix el camí de les grans dives. Hi ha una altra cantant que viu a Borriana i que té un futur prometedor en el món del cant clàssic: Iris Almenara (1989).

La germana gran de Minerva Moliner és Eugenia (1970), la flauta travessera borrianenca que més lluny ha arribat en el món de la música clàssica. Flautista de reconeguda qualitat, viu a Chicago on, probablement, les possibilitats de viure de la música d'alt nivell són millors que a Borriana. Eugenia és, a hores d'ara, una de les millors flautistes del món, àmpliament lloada per la seua musicalitat, i forma amb Denis Azabagic un dels millors duos guitarra i flauta que existeixen: Cavatinaduo. Una deixebla reeixida d'Eugenia Moliner és la també borrianenca Maria Bernat (1981), professora de flauta travessera del Conservatori de Castelló, que ha estudiat en diversos punts d'Europa i dels Estats Units.

En qüestió de clarinetistes, Borriana ha estat un nucli destacat. Des dels quasi ancestres Ximet de la Mateua, Juan Kavalireck, l'Austríac, i Solà (Buris-ana, 2005: 6), la Banda de Borriana no ha cessat de produir clarinetistes, tots ells devots de l'instrument i alguns i algunes que han fet de l'aeròfon de llengüeta simple l'ofici de la seua vida. Entre els actuals, en destaquem Norma Comes Vidal, per la seua trajectòria com a instrumentista, però també com a professora de clarinet; formada en la Banda de Borriana. Però, en el cas dels clarinets, el borrianenc que ha arribat més alt, ja als 
vint-i-set anys, és Raúl Traver, reconegut solista internacional amb nombrosos premis, que estudia a Califòrnia i al Conservatori Reina Sofía de Madrid.

Destaquem també altres bons músics i professors d'instrument actuals que van començar en la Filharmònica Borrianenca a finals dels anys vuitanta i als noranta i que són referents nacionals del seu instrument. D’una banda, David Guillamón, percussionista borrianenc que ha estat membre d'orquestres d'arreu d'Espanya i també a Alemanya. Com a professor de percussió del Conservatori de Borriana, ha creat escola i té nombrosos i aplicats deixebles, dels quals en destaca un dels primers: Jesús David Valero (1987). Podríem seguir parlant dels molts músics professionals que actualment hi ha a Borriana, però l'espai ens priva d'aquesta devoció. Per acabar, citarem una jove pianista i compositora amb molta projecció de futur: Paula Traver, i altres excel·lents músics actuals borrianencs com ara Salvador Sebastià (1972, director de trajectòria precoç i dilatada i professor al Conservatori Superior Joaquim Rodrigo de Castelló), Santiago Pla (actual trompa solista de l'Orquestra de València), Ana Pitarch (violoncel·lista i professora), Guillem Calpe (1990, actual estudiant de composició i de direcció a Amsterdam) i, sense més dilació, deixem la línia oberta per si algú vol afegir-s'hi.

\section{Literatura}

Sens dubte, la figura de lletres més important que Borriana ha tingut fins als nostres dies ha estat Rafel Martí de Viciana (1502-1582). Cronista destacat de la seua època, és considerat per alguns l'historiador valencià més important del segle XVI. Va participar en la guerra de les Germanies en contra dels agermanats. La seua obra més important és la Crònica de València, composta de quatre volums, la qual va ser escrita en valencià i posteriorment traduïda al castellà per motius polítics, i publicada l'any 1564 amb el nom de Crónica de la ínclita y coronada ciudad de Valencia y de su reyno. ${ }^{3}$ Aleshores, Borriana encara era una de les ciutats més importants del Regne de València i, per tant, un centre neuràlgic historicocultural. Si Martí de Viciana haguera nascut els nostres dies, no l'hauríem inclòs en aquest capítol, ja que no hi ha molt d'artístic en una obra més aviat humanisticocientífica com la seua. En canvi, per la importància de la seua figura i per les escasses fronteres entre art i cultura, en general, existents en el període humanista - això és un invent racionalista de segles després-, hem considerat interessant començar a parlar de literatura recordant aquest il·lustre literat borrianenc. Perquè en la seua figura insigne queda reflectit el pes específic de la Borriana catalanoaragonesa.

Després del gran historiador, fem un salt cronològic de tres segles i ens presentem en la segona meitat del segle XIX, ja que no disposem d'informació substancial sobre els escriptors d'aquests segles que en la història de la literatura catalana s'han considerat tan foscos. La Borriana de la segona meitat del XIx i de l'inici del xx és la del boom de la taronja. Borriana recupera la seua posició de nucli econòmic. Com ha ocorregut —almenys fins ara-,

\footnotetext{
${ }^{3}$ Del tercer volum d'aquesta obra de Martí de Viciana és el dibuix tan característic de la Borriana del segle XVI, emmurallada i esfèrica segons l'historiador, una rèplica del qual es troba a la plaça la Mercè en forma de maqueta de bronze.
} 
l'augment del poder adquisitiu de la burgesia i dels treballadors implica el creixement de l'activitat cultural i concretament artística. Així, en aquesta època apareixen una vintena de publicacions locals i, com hem vist en l'apartat dels músics, hi ha llocs neuràlgics de cultura i de comerç com el Casino Borrianenc. Justament el casino va esdevenir la seu d'una agrupació científica, artística i literària, anomenada La Grillera (Esteve i Garí, 1989: 19).

Aquesta associació, més aviat efímera, va operar de 1898 a 1902. Cada mes convocava un certamen de creació literària a la manera jocfloralista, tan de moda pels volts del xx -i que encara cueja en certs contextos fallers. Al voltant de La Grillera hi hagué lletraferits com Josep Calzada Carbó (1878-1965) i Joan Baptista Tejedo Beltran (1877-1952). Manuel Peris Fuentes (1857-1932) no va participar en La Grillera, però també féu poesia. De fet, tots cultivaven la poesia, però alguns també provaren amb altres gèneres literaris. Calzada va escriure poesia i narrativa. Peris, poesia i teatre. Tanmateix, el poeta borrianenc més important d'aquesta època, els versos del qual eren recitats pels seus conciutadans, ha estat Tejedo Beltran de qui destaca, per la seua popularitat, el llibret Pere, el qual va ser editat l'any 1902 i reeditat en 1944 (Esteve i Garí, 1989: 21-22).

No voldríem deixar d'esmentar Vicent Moliner Nadal (1903-1940), l'últim alcalde republicà de Borriana, que va escriure a la presó uns poemes en castellà que esgarren l'ànima i d'alguns dels quals se'n conserven originals (Doñate, 2006). ${ }^{4}$ Són testimonis esfereïdors que narren el dolor d'un home republicà i socialista que va romandre estoicament al seu poble, i va exercir-hi de governant en els anys de la guerra civil, que va lluitar perquè els borrianencs comptaren amb queviures quan hauria pogut fugir del poble i del país. Com a recompensa, va obtenir un any llarg de presó i una condemna a mort que es va executar el 21 de maig de 1940, amb el seu afusellament a la rambla del riu Sec, al costat del cementiri de Castelló.

Un altre cas excepcional és el d'Artur Perucho Badia (1902-1956), nascut a Borriana, però que no hi va residir a penes. Aquest escriptor, periodista i activista polític va viure almenys a Borriana, a Xàtiva, a Barcelona i a Mèxic. En el seu periple vital, ple de maletes, trens i avions, va treballar de periodista i va escriure estudis de recerca com Catalunya sota la dictadura (1930) i Resum de literatura russa (1933). Però el citem ací especialment pel seu vessant de novel-lista i per una novel-la imprescindible de la literatura catalana com és Ícar o la impotència (1929). També va escriure teatre, almenys tres obres. Finalment, el seu compromís polític amb els ideals republicans el va dur a l'exili mexicà (Esteve, 2007: 348-349). Un altre borrianenc instal·lat a Amèrica és Francisco Planelles (1936), qui ha escrit nostàlgicament sobre el seu poble, Borriana, des de l'Uruguai, on ha viscut aproximadament mig segle.

En la seua Història de la literatura del segle xх a Borriana, publicada l'any 1989, Teresa Esteve i Joan Garí divideixen l'estudi en dues parts i utilitzen la guerra civil com a frontissa. Arribats a l'any 1939, la conjuntura canvia diametralment. Es perd la llibertat d'expressió: no es pot escriure en català ni contradir l'esperit nacionalcatolicista. En aquest context es va crear la revista Buris-ana (1956), dos anys després del naixement de l'ABC.

\footnotetext{
${ }^{4}$ Els poemes de Vicent Moliner Nadal es poden consultar en el número 199 de la revista Buris-ana que és el de juny de 2006. Aquest número inclou un facsímil de trenta pàgines on es recullen els poemes de Moliner que es conserven així com les investigacions sobre aquesta víctima del franquisme dutes a terme per Vicent Abad i per Raquel Doñate, qui ha estat l'encarregada de compendiar els seus versos i de contextualitzar-los.
} 
Josep Aymerich Tormo, Joaquim Urios i Vicent Monsonís Moros, entre d'altres, en van ser els responsables.

Pel que fa a la poesia dels anys del franquisme i de la transició, hi va haver un grup de poetes que va optar pel continuisme (Esteve i Garí, 1989: 46) costumista, populista i per això poc problemàtic amb el règim. Parlem de Josep Aymerich Tormo, Joaquim Urios, Vicent Monsonís Moros i Josep Esteve Patuel. Aquest darrer es va desmarcar una mica, potser pel seu to més general i una subtil introducció de contingut ideològic (Ibídem). D'altra banda, hi ha Josep Fèlix Escudero (nascut a Atzeneta l'any 1946, però considerat de Borriana), amb un afany més innovador i que va escriure part de la seua poesia en català.

Pel que fa a la poesia de les dones, Carme Rufino i Teresa Esteve, ${ }^{5}$ ambdues nascudes als anys seixanta, han publicat versos en català, mentre que Gema Gimeno, nascuda en els setanta, ha fet les seues provatures poètiques en castellà. Ens queden per comentar encara dues veus poètiques masculines en català: una de prou consolidada com és la d'Iban Leon Llop (1975), que compta amb diversos premis i publicacions dels seus poemes, i la d'Ivan Parra (1993), promesa encara de futur que, sent menor d'edat va publicar, a Bromera, un recull de poemes l'any 2011.

Josep Palomero (1953) va començar escrivint poesia tot i que posteriorment ha estat més reconegut per la seua narrativa. El seu germà Miquel Palomero (1961) també ha publicat alguna novel-la que li ha estat premiada, com és el cas de Gònades tibants (2003). El cas de Vicent Abad com a novel-lista és peculiar. Aquest estudiós, nascut el 1930, que ha redactat nombrosos capítols de la història econòmica i social de la Borriana citrícola, sorprèn l'any 2005 amb la seua primera novel·la, El jardín de las Hespérides, un relat costumista emmarcat en els anys de la capitalitat tarongera de Borriana.

Com li ha passat a Josep Palomero, Vicent Franch (1949) és també més narrador que poeta. Joan Jesús Pla Villar (nascut a Artana el 1942, però que ha viscut i treballat a Borriana) ha assolit el reconeixement en l'àmbit literari català com a escriptor de novel·la juvenil. També mestre, com Jesús Pla, Antoni Dualde Saborit (1976) fa poc que s'ha estrenat com a autor de literatura infantil i juvenil amb el recull de relats breus Deu miratges (2008). Un altre narrador borrianenc que escriu en català és Octavi Monsonís (1949). La seua darrera novel·la en català, publicada en 2013, és Carrer de pas.

Podríem afirmar que Joan Garí és el més prolífic i polifacètic dels escriptors borrianencs actuals. Aquest assagista i narrador que escriu en català i que, com molts d'altres, també va començar amb el cultiu del vers, ha estat guardonat en nombroses ocasions i escriu incansablement narrativa i assaig. Per a tancar aquest punt, parlarem de dos joves novel-listes locals: Enrique Planelles (1970), que en 2013 ha publicat la seua primera novel·la titulada Los desdichados, i Ángel Gil Cheza (1974, que és de Vila-real però que manté una estreta relació amb Borriana) que té diverses novel·les publicades, la darrera de les quals, de 2012, es titula La lluvia es una canción sin letra. També hi ha a Borriana un jove escriptor de guions audiovisuals de ficció: Marc Jarques (1989).

\footnotetext{
${ }_{5}^{5}$ Teresa Esteve. Gràcies per la teua tasca que tant ha facilitat la meua en aquest text. I gràcies per ser dona i poetessa borrianenca.
} 


\section{Reflexió final}

Aquest poble l'estimen molts artistes locals com s'estima la família: amb els seus defectes i tot. És una família que els fills i les filles artistes voldrien que fóra millor en molts sentits, però que alhora defensen aferrissadament contra les crítiques externes. Perquè és la seua única família i original: amb les seues borumballes i fums de canya, les seues ombres i clarobscurs, els racons incomprensiblement tristos i dramàtics i la violència cultural; però alhora és una Borriana tan bella com una mar mediterrània, com un riu sec, com un campanar majestuós i remot, i uns carrers antics i condensats de memòria.

Hi ha joves que són encara promeses de futur per a l'art de Borriana - malgrat els mèrits que hagen pogut obtenir ja. Tenen al seu abast un nou univers cultural que sorgeix com una au fènix de les cendres de l'antic règim que ha estat l'era analògica. Es troben enfront d'una nova manera de mastegar influències i d'un nou concepte d'autoria, on autor i obra es desdibuixen alhora que passen a formar part d'una xarxa molt més orgànica cada dia.

\section{BIBLIOGRAFIA}

Buris-ana (2005) Monogràfic sobre música: «Borriana en clau musical», 195 [abril].

Buris-ana (2006) Monogràfic sobre la figura de Vicente Moliner Nadal, 199 [juny].

Buris-ana (2009) Monogràfic sobre cinema: «Borriana de cine», 209 [novembre].

Esteve, T. (2007): «Artur Perucho i Badia, Ícar o la impotència», dins: Les Normes del 32. Els escriptors castellonencs, València, AVL, 348-349.

Esteve, T. i J. Garí (1989): La Terra que està més endins: literatura a Borriana: 1900-1988, Borriana, Ajuntament de Borriana.

Garcia Ferrada, J.L. (1986): Pell de taronja. Mig segle d'arquitectura a Borriana (1890-1940), Borriana, Ajuntament de Borriana.

GARÍ, J. (2008): «El món de Ramon Usó», Buris-ana, 206, 8-11.

Mesado, G. (2005): «Recordant Abel Mus», Buris-ana, 195, 10-12.

Roselló, M. (2009): «Forja d'artistes. L'ensenyança d'arts plàstiques a Borriana (1955-1991)», Buris-ana, 207, 15-17.

SACKs, O. (2008): Musicophilia: tales of music and the brain, Nova York, Vintage Books.

$<$ www.antonipinyol.com>.

\section{BIONOTA}

\section{Aina Monferrer Palmer}

Nascuda a Borriana (1987), és títol professional de Música (especialitat de Violí), llicenciada en Comunicació Audiovisual, grau en Filologia Catalana i màster en Comunicació Intercultural en l'Ensenyament de Llengües. Actualment treballa en el Departament de Filologia i Cultures Europees de la Universitat Jaume I com a investigadora predoctoral amb càrrega docent. La tesi doctoral que prepara, sota la direcció de Vicent Salvador, es titula «Estudi lingüístic, literari i textual de la poesia de Vicent Andrés Estellés en un marc d'interessos didàctics i traductològics». 